OPEN ACCESS

Edited by:

Jasminka Z. llich,

Florida State University, United States

Reviewed by:

Dario Coletti,

Sapienza University of Rome, Italy

Meghit Boumediene Khaled,

University of Sidi-Bel-Abbès, Algeria

*Correspondence:

Ingrid Elisia

ielisia@bccrc.ca

Specialty section:

This article was submitted to

Clinical Nutrition,

a section of the journal

Frontiers in Nutrition

Received: 29 November 2020 Accepted: 05 February 2021

Published: 25 February 2021

Citation:

Elisia I and Krystal G (2021) The Pros and Cons of Low Carbohydrate and Ketogenic Diets in the Prevention and

Treatment of Cancer.

Front. Nutr. 8:634845

doi: 10.3389/fnut.2021.634845

\section{The Pros and Cons of Low} Carbohydrate and Ketogenic Diets in the Prevention and Treatment of Cancer

\section{Ingrid Elisia* and Gerald Krystal}

The Terry Fox Laboratory, BC Cancer, Vancouver, BC, Canada

Ketogenic diets are low carbohydrate $(\mathrm{CHO})$, high fat diets that are currently very popular for weight loss. Since cancer cells typically consume far more glucose than normal cells, low $\mathrm{CHO}$ diets are currently being considered as possible therapeutic regimens to manage cancer. However, our understanding of the safety and efficacy of such $\mathrm{CHO}$-restricted diets in the prevention and treatment of cancer is still in its infancy. In this perspective we provide an overview of the current state of knowledge regarding the use of low $\mathrm{CHO}$ diets in the prevention and treatment of cancer. We also highlight the gaps in our knowledge regarding the potential usefulness of low $\mathrm{CHO}$ diets in cancer. While pre-clinical rodent studies have provided convincing evidence that $\mathrm{CHO}$ restriction may be effective in reducing cancer growth, there has not been sufficient attention given to the effect of these low $\mathrm{CHO}$ diets, that are often high in fats and low in soluble fiber, on inflammation. This is important, given that different fats have distinct effects on inflammation. As well, we demonstrate that short chain fatty acids, which are produced via the fermentation of fiber by our gut microbiome, have more anti-inflammatory properties than $\beta$-hydroxybutyrate, a ketone body produced during nutritional ketosis that is touted to have anti-inflammatory activity. Since chronic inflammation is strongly associated with cancer formation, defining the type of fats in low $\mathrm{CHO}$ diets may contribute to our understanding of whether these diets may work simply by reducing glucose bioavailability, or via modulation of inflammatory responses.

Keywords: ketogenic, low carbohydrate, cancer, safety, prevention, treatment, inflammation

\section{INTRODUCTION}

Low carbohydrate $(\mathrm{CHO})$ diets restrict $\mathrm{CHO}$ intake while increasing fat and/or protein. There are currently many low $\mathrm{CHO}$ diets, including ketogenic diets, and they vary in their stringency of $\mathrm{CHO}$ restriction and the amount as well as type of fat and protein $(1,2)$. Historically, the ketogenic diet was first used in the 1920s to treat pediatric epilepsy (3). The use of CHO restriction for weight loss was popularized a couple of decades later with the introduction of the Atkins diet (4). Today, ketogenic diets are immensely popular as a weight loss regimen (5).

In this perspective, we provide an overview of the current state of knowledge regarding the safety and efficacy of low $\mathrm{CHO}$ diets for cancer prevention and treatment. In addition, we propose further studies to bring $\mathrm{CHO}$ restriction therapy into the clinic, specifically for cancer. 


\section{CARBOHYDRATE RESTRICTION AND CANCER}

In the 1920s, Otto Warburg observed that cancer cells take up more glucose than normal cells and convert it via glycolysis to lactic acid $(6,7)$. This characteristic of cancer cells has been called the Warburg effect or aerobic glycolysis (since this increased glycolysis occurs even when adequate oxygen is present) (6). This was an unexpected finding since glycolysis is inefficient at producing ATP, generating only 2 ATPs/glucose, and cancer cells typically need lots of energy for their uncontrolled proliferation (6). As well, it was thought at that time that cells only relied on glycolysis under anaerobic conditions, since the downstream citric acid cycle, which converts pyruvate to carbon dioxide and generates far more ATP than glycolysis, requires oxygen to operate $(6,7)$. However, cancer cells, and all rapidly growing cells, prefer increasing glycolysis over increasing the citric acid cycle since it generates both reduced glutathione to combat oxidative stress (which is increased in cancer cells and can kill them) and biosynthetic precursors required to support cell proliferation (6). Since cancer cells take up and need more glucose than normal cells, it is therefore reasonable to hypothesize that a reduction in $\mathrm{CHO}$ intake, which increases glucose in the blood, might help prevent or treat cancer.

Another possible mechanism by which $\mathrm{CHO}$ restriction, and specifically a ketogenic diet, might slow cancer growth is through the generation of ketone bodies, since there is some evidence that many cancer cells, unlike normal cells, cannot use ketone bodies as an energy source (8-10). Ketone bodies are generated via fatty acid oxidation in the liver when blood glucose levels drop. They then travel in the blood to all our cells and are converted into acetyl-CoA by $\beta$-OHB dehydrogenase 1 (BDH1), succinyl-CoA:3oxoacid-CoA transferase (SCOT) and acetoacetyl-CoA thiolase and enter the citric acid cycle to generate $\operatorname{ATP}(11,12)$. However, while many cancer cells do not appear to have the enzymes required to break down ketone bodies to acetyl-CoA, and are therefore at a selective disadvantage in a low glucose environment $(8-10,13)$, some cancer cell types do (10) so a ketogenic diet may not be effective at preventing or treating all cancers.

\section{THE SAFETY OF LOW CARBOHYDRATE DIETS}

Adoption of low $\mathrm{CHO}$ diets in humans has received pushback from the scientific community because a reduction in $\mathrm{CHO}$ is often compensated by an increase in fat, which typically includes saturated fats. This is often the main criticism of low $\mathrm{CHO}$, high fat diets, i.e., the consumption of high amounts of saturated fat may lead to increased levels of $\operatorname{LDL}$ cholesterol $(14,15)$, which in turn raises cardiovascular risk $(16,17)$. There are now, however, many clinical trials demonstrating that consumption of saturated fats in the context of low $\mathrm{CHO}$, high fat diets, while increasing LDL cholesterol, tends to reduce plasma triglycerides and increase HDL cholesterol $(14,18,19)$. In keeping with this, a recent meta-analysis reported no association between intake of saturated fats and all cause mortality, cardiovascular disease, and coronary heart disease mortality. However, an association with trans fats was reported (20). Furthermore, low $\mathrm{CHO}$, high fat diets appear to reduce small, dense $\operatorname{LDL}$ cholesterol $(21,22)$, which is thought to be the type of cholesterol associated with coronary artery disease $(17,23)$. However, these clinical trials are relatively short term and there is still a lack of long-term studies evaluating the effect of low $\mathrm{CHO}$, high fat diets on cardiovascular disease.

\section{LOW CARBOHYDRATE DIETS IN PRE-CLINICAL STUDIES}

The potential efficacy of low $\mathrm{CHO}$ or ketogenic diets to prevent or treat cancer has been obtained primarily from rodent studies. Many of these studies have employed either human cancer cells in immunocompromised mice (xenograft models), or implanted murine tumor cells in syngeneic mice (24). Using these model systems, we and others have demonstrated that low $\mathrm{CHO}$ diets exhibit anti-tumor activity against colon (25-28), gastric (29), prostate (30,31), head and neck (26), brain (32-35), and thyroid (35) cancer. A more extensive list of publications reporting the efficacy of $\mathrm{CHO}$ restrictive diets or ketogenic diets in slowing tumor growth in rodent model systems can be found in a recent review by Weber et al. (24).

Despite these promising results, there are other studies demonstrating that low $\mathrm{CHO}$, high fat diets promote cancer progression (36). For example, Zhang et al. (10) have demonstrated that specific cancer cells possess the ketolytic enzymes required to break down ketone bodies to acetyl Co-A, and this in turn can feed into the citric acid cycle and be used to generate ATP. It is thus possible that the efficacy of a ketogenic diet will turn out to be dependent on whether the cancer cells express high or low levels of enzymes involved in converting ketone bodies to acetyl-CoA.

Results from our lab have demonstrated that a low $\mathrm{CHO}$, high protein diet effectively lowers blood glucose and insulin levels and this is paralleled by a reduction in the growth of subcutaneously implanted murine and human cancer cells (26). We also showed that the same diet reduced tumor penetrance in a transgenic mouse model of HER-2/Neu-induced mammary cancer, while extending the lifespan of these mice (26). When combined with celecoxib, a cyclooxygenase 2 (COX2) inhibitor, this low $\mathrm{CHO}$, high protein diet not only reduced lung metastasis of $4 \mathrm{~T} 1$ mammary tumors in Balb/C mice, but also lowered the incidence of metastasis in the male Transgenic Adenocarcinoma of the Mouse Prostate (TRAMP) mice (37). This is despite not observing a significant change in LNCaP xenograft tumor growth (38). In castrated mice, however, our low $\mathrm{CHO}$, high protein diet was effective in slowing tumor growth (38).

While xenografts or implanted tumor models are valuable at identifying agents that can slow the growth of established tumors, they cannot evaluate effects on tumor incidence. As well, xenografts typically rely on immunocompromised mice, which rules out the possible interaction between diets and the immune system, a relationship that we now appreciate plays an important role in cancer development (39). In addition, most cancers arise 
from somatic mutations that occur over a long period of time, and not from genetic mutations or from implanted tumors, which the above models represent (40).

To determine if $\mathrm{CHO}$ restriction might have an impact on cancer initiation and progression in a longer-term model, we tested the effect of a low $\mathrm{CHO}$ diet in preventing the formation of cigarette smoke carcinogen (NNK)-induced lung cancer in $\mathrm{A} / \mathrm{J}$ mice (41). Specifically, we gave these A/J mice a Western diet or a variety of low $\mathrm{CHO}$, high fat diets prior to NNK injections, which are needed to initiate lung cancer formation. In these studies, we evaluated the effect of different $\mathrm{CHO}$, protein and fat types. Specifically, we compared the effect of carbohydrate types, soy protein vs. casein, as well as a blend of fats typically found in a Western diet with ones enriched in fish oil or coconut oil. Comparing the effect of fat types in a low $\mathrm{CHO}$, high fat diet in this study is a particularly important research question to address since there have been very few studies to date clarifying the contribution of different fat types on the efficacy of the diet. Fish oil is an important source of omega 3 fatty acids such as eicosapentaenoic acid (EPA) and docosahexaenoic acid (DHA), while coconut oil is a popular type of fat that is often consumed in a ketogenic diet because of its high level of medium chain fatty acids (42). Medium chain triglycerides (MCTs) are reported to be more readily utilized for fatty acid oxidation than long chain fatty acids (43). Thus, they are metabolized for ATP generation more readily than longer chain fatty acids (43).

From these studies we demonstrated that while $\mathrm{CHO}$ restriction alone was sufficient to reduce NNK-induced lung nodule formation, partial substitution of the fats typically consumed in a Western diet with fish oil produced a far more robust reduction in lung nodule formation (41). On the other hand, incorporation of coconut oil had no impact on lung nodule count. In addition, when soy protein was included in the low $\mathrm{CHO}$, high fish oil diet instead of casein, there was a further suppression of lung cancer formation, suggesting the superiority of soy protein over this milk protein.

This low CHO diet containing soy protein and enriched in fish oil also proved effective in slowing tumor growth in the NNK-induced lung cancer model when given to mice after lung nodules were established (44). Interestingly, in these studies with already established tumors, mice fed with this low $\mathrm{CHO}$ diet had similar tumor stage progression and tumor cell proliferation rates to mice on a Western diet but increased cleaved caspase 3, suggesting that the diet-induced reduction in tumor size could be attributed, at least in part, to the ability of the diet to induce apoptosis in the tumors (44).

Taken together, our studies suggest that while lowering glucose bioavailability may alone be an effective strategy to prevent cancer formation, incorporation of soy protein and fish oil into such low $\mathrm{CHO}$ diets may dramatically improve the efficacy of these diets in reducing lung cancer risk.

\section{EFFECT OF LOW CARBOHYDRATE DIETS ON INFLAMMATION}

It is currently clear that chronic inflammation is a risk factor for cancer (45). Low grade chronic inflammation that does not resolve may lead to DNA mutations that can trigger cancer formation. At the same time, tumor-promoting inflammation is a critical component of cancer progression and is now one of the hallmarks of cancer (46). Considering the important contribution of inflammation to cancer, consumption of a diet or dietary component(s) that may modulate inflammation may be beneficial in both cancer prevention and treatment.

From our studies, it is apparent that a reduction in blood glucose alone may not give a robust reduction in lung cancer risk (41). While all versions of the low $\mathrm{CHO}$ diets we tested were effective in lowering blood glucose levels, the low $\mathrm{CHO}$ diet containing soy protein and fish oil was not only the most effective at lowering lung nodule formation but also the most effective at reducing insulin and pro-inflammatory cytokine levels (IL6 , IL-1 $\beta$, and TNF- $\alpha)(41,44)$. This suggests multi-pronged mechanisms may be at play in preventing cancer formation. For example, since fish oil is high in omega 3 PUFAs (EPA/DHA), it is possible that the omega 3 fatty acids play a critical role in reducing chronic inflammation and this, in turn, reduces the risk of lung tumor formation (47).

One of the major concerns regarding a $\mathrm{CHO}$ restrictive diet is its potential to promote inflammation because of the large amount of fats, particularly saturated fats, typically consumed in such diets $(48,49)$. While different types of fats may elicit pro- or anti-inflammatory responses, saturated fat has been shown to mimic lipopolysaccharide (LPS), which induces inflammation upon binding to this receptor on the surface of macrophages/monocytes and other innate immune cells $(48,50)$. On the other hand, polyunsaturated fats such as the omega 3 fatty acids, EPA and DHA, have been shown to exhibit antiinflammatory effects $(48,51)$. Currently, most diet studies do not report their fatty acid composition other than whether the fatty acids are saturated or unsaturated (Table 1). This is a serious omission since, as mentioned, EPA and DHA, have anti-inflammatory activities that are not observed with other polyunsaturated fatty acids such as the omega 6 fatty acid, arachidonic acid (79). It is also known that it takes months for tissue EPA/DHA levels to peak, which means that the full effect of these high fat diets may only be detected in long term studies (80).

Despite the often-increased intake of saturated fats, many studies evaluating the effect of $\mathrm{CHO}$ restrictive diets on inflammatory markers suggest that these diets reduce or have no effect on inflammation (Table 1). An important caveat in these studies, however, is that C-reactive protein (CRP) and IL6 , inflammatory markers commonly used to assess inflammatory status in these studies, are positively correlated with obesity (81). Since low $\mathrm{CHO}$ diets often inadvertently lead to lower calorie intake, which leads to the observed weight loss in these studies (Table 1) $(67,68,82)$, it is possible that the observed reduction in CRP is attributable to diet-induced weight loss rather than the diet components themselves $(60,77,83)$. As well, while Forsythe et al. (65) have demonstrated that increased saturated fat consumption does not translate to increased circulating saturated fat, the gastrointestinal (GI) tract remains exposed to a large quantity of fat in a low $\mathrm{CHO}$, high fat/ketogenic diet. Increased fat intake may stimulate bile acid secretion, required to emulsify fat and promote intestinal absorption, and this bile acid may then be recycled in the liver to generate a secondary bile acid 
TABLE 1 | Effect of low carbohydrate diets on metabolic and inflammatory markers that may influence cancer risk.

\begin{tabular}{|c|c|c|c|c|c|c|c|c|c|c|c|c|c|c|c|c|}
\hline $\begin{array}{l}\text { No of } \\
\text { subjects }\end{array}$ & $\mathrm{CHO}$ intake & $\begin{array}{l}\text { CHO: } \\
\text { protein: } \\
\text { fat (kcal) } \\
\text { ratio }\end{array}$ & $\begin{array}{l}\text { Saturated: } \\
\text { monounsaturated: } \\
\text { Polyunsaturated } \\
\text { fats ratio }\end{array}$ & $\begin{array}{l}\text { Type of } \\
\text { fatty acids }\end{array}$ & Duration & $\begin{array}{l}\text { Compared } \\
\text { to }\end{array}$ & $\begin{array}{l}\text { Reduced } \\
\text { calorie } \\
\text { intake }\end{array}$ & $\begin{array}{l}\text { Peak BHB } \\
\text { (mM) }\end{array}$ & Weight & $\begin{array}{l}\text { Blood } \\
\text { glucose }\end{array}$ & Insulin & CRP & IL6 & $\begin{array}{l}\text { TNF- } \\
\alpha\end{array}$ & $\begin{array}{l}\text { Other } \\
\text { inflammatory } \\
\text { markers }\end{array}$ & References \\
\hline $\begin{array}{l}33 \text { Obese with } \\
\text { MetS }\end{array}$ & $<20-40 \mathrm{~g} / \mathrm{d}$ & $4: 35: 61$ & $40: 46: 14$ & & $12 \mathrm{mo}$ & Baseline & Yes & $\sim 0.5$ & $\downarrow$ & $\downarrow$ & $\downarrow$ & $\downarrow$ & & & & (18) \\
\hline $\begin{array}{l}52 \\
\text { Overweight/ } \\
\text { obese }\end{array}$ & & $4: 35: 61$ & & & $8 w k$ & Baseline & & & $\downarrow$ & $\downarrow$ & $\downarrow$ & $\downarrow$ & & & & (52) \\
\hline $\begin{array}{l}10 \text { Obese with } \\
\text { NAFLD }\end{array}$ & $23-30 / d$ & $4: 24: 72$ & & & $2 w k$ & Baseline & Isocaloric & $\sim 2$ & $=$ & & & & $\downarrow$ & $\downarrow$ & & (53) \\
\hline 51 Diabetic & $20-25 \mathrm{~g} / \mathrm{d}$ & $5: 20: 75$ & & & $6 \mathrm{mo}$ & Low fat diet & & & $\downarrow$ & $=$ & & $=$ & $=$ & & $\begin{array}{l}\text { Soluble } \\
\text { E-selectin }(\downarrow), \\
\text { ICAM1 }(\downarrow)\end{array}$ & (54) \\
\hline 35 Obese & & $5: 20: 75$ & $33: 22: 7$ & & 12 wk & Baseline & $\begin{array}{l}\text { Initial } \\
2 \text { weeks }\end{array}$ & $\sim 2$ & $\downarrow$ & $=$ & $\downarrow$ & $=$ & & & & (55) \\
\hline $\begin{array}{l}17 \text { Healthy } \\
\text { men }\end{array}$ & & $5: 15: 80$ & & & 4 wk & $\begin{array}{l}\text { Habitual } \\
\text { diet }\end{array}$ & Yes & 0.77 & $\downarrow$ & 0 & $\downarrow$ & $\uparrow$ & $=$ & & & (56) \\
\hline 19 Overweight & & 5:31:64 & 39:33:16 & & $7 d$ & Baseline & & & $\downarrow$ & $\downarrow$ & & $=$ & $=$ & & MCP1 $(\downarrow)$ & (57) \\
\hline 9 Healthy & $<50 \mathrm{~g} / \mathrm{d}$ & $7.5: 27: 65$ & & & 4 wk & $\begin{array}{l}\text { Habitual } \\
\text { diet }\end{array}$ & & 0.7 & $\downarrow$ & 0 & & & $=$ & & & (58) \\
\hline $\begin{array}{l}15 \text { Overweight } \\
\text { men }\end{array}$ & & 8:28:63 & 44:36:20 & & $6 \mathrm{wk}$ & Baseline & Yes & & $\downarrow$ & & & $\downarrow$ & $\downarrow$ & $\downarrow$ & ICAM1 $(\downarrow)$ & (59) \\
\hline 15 Obese & $<40 \mathrm{~g} / \mathrm{d}$ & $10: 34: 56$ & $41: 42: 17$ & & 12 wk & Baseline & Yes & & $\downarrow$ & $\downarrow$ & $\downarrow$ & $\downarrow$ & & $=$ & & (60) \\
\hline $\begin{array}{l}10 \text { Healthy } \\
\text { women }\end{array}$ & & 10:30:60 & 42:36:21 & & 4 wk & Baseline & & & & & & $=$ & $=$ & $=$ & & (14) \\
\hline 16 Diabetics & & $10: 25: 65$ & 23:60:17 & & $4 d$ & Baseline & & & $\downarrow$ & $\downarrow$ & $=$ & & $=$ & $=$ & $\begin{array}{l}\operatorname{MCP} 1(=), \\
\operatorname{pJNK}(\downarrow), \\
\operatorname{IL} 10(=), \text { IL18 } \\
(=)\end{array}$ & (61) \\
\hline $\begin{array}{l}21 \text { Statin } \\
\text { takers }\end{array}$ & $<50 \mathrm{~g} / \mathrm{d}$ & 11:28:58 & $51: 35: 14$ & & 6 wk & Baseline & Yes & $\sim 0.5$ & $\downarrow$ & $=$ & $\downarrow$ & $=$ & $=$ & $=$ & $\begin{array}{l}\text { IL8 }(=) \text {, soluble } \\
\text { E-selectin }(\downarrow) \text {, } \\
\text { ICAM-1 }(\downarrow)\end{array}$ & (62) \\
\hline \multirow[t]{2}{*}{$\begin{array}{l}34 \text { Overweight } \\
\text { male }\end{array}$} & & 11:43:46 & & EPA/DHA & 4 wk & $\begin{array}{l}\text { No omega } \\
3 \text {, ketogenic } \\
\text { diet }\end{array}$ & & & $=$ & $=$ & $\downarrow$ & & $\downarrow$ & $\downarrow$ & $\operatorname{IL} 1 \beta(\downarrow)$ & (63) \\
\hline & & & & & & Baseline & Yes & & $\downarrow$ & $\downarrow$ & $\downarrow$ & & $\downarrow$ & $\downarrow$ & $\operatorname{IL} 1 \beta(\downarrow)$ & \\
\hline 20 Overweight & & 12:29:59 & 48:35:16 & Described & $12 \mathrm{wk}$ & Low fat diet & Yes & & $\downarrow$ & & & $\downarrow$ & $=$ & $\downarrow$ & $\begin{array}{l}\text { VEGF }(\downarrow) \text {, } \\
\text { P-selectin }(\downarrow), \\
\text { IL8 }(\downarrow), \text { MCP1 } \\
(\downarrow), \text { E-Selectin } \\
(\downarrow), \text { PAI }(\downarrow), \\
\text { ICAM-1 }(\downarrow)\end{array}$ & (64) \\
\hline
\end{tabular}


TABLE 1 | Continued

\begin{tabular}{|c|c|c|c|c|c|c|c|c|c|c|c|c|c|c|c|c|}
\hline $\begin{array}{l}\text { No of } \\
\text { subjects }\end{array}$ & $\mathrm{CHO}$ intake & $\begin{array}{l}\text { CHO: } \\
\text { protein: } \\
\text { fat (kcal) } \\
\text { ratio }\end{array}$ & $\begin{array}{l}\text { Saturated: } \\
\text { monounsaturated: } \\
\text { Polyunsaturated } \\
\text { fats ratio }\end{array}$ & $\begin{array}{l}\text { Type of } \\
\text { fatty acids }\end{array}$ & Duration & $\begin{array}{l}\text { Compared } \\
\text { to }\end{array}$ & $\begin{array}{l}\text { Reduced } \\
\text { calorie } \\
\text { intake }\end{array}$ & $\begin{array}{l}\text { Peak BHB } \\
\text { (mM) }\end{array}$ & Weight & $\begin{array}{l}\text { Blood } \\
\text { glucose }\end{array}$ & Insulin & CRP & IL6 & $\begin{array}{l}\text { TNF- } \\
\alpha\end{array}$ & $\begin{array}{l}\text { Other } \\
\text { inflammatory } \\
\text { markers }\end{array}$ & References \\
\hline 8 Men & & $12: 30: 58$ & $30: 44: 26$ & Described & 6 wk & Baseline & No & 0.26 & $=$ & $=$ & $=$ & $=$ & $=$ & $=$ & $\begin{array}{l}\text { IL8 (=), MCP1 } \\
(=)\end{array}$ & (65) \\
\hline $\begin{array}{l}29 \text { Overweight } \\
\text { women }\end{array}$ & & $12: 30: 58$ & & & 4 wk & Baseline & Yes & & $\downarrow$ & $=$ & & $\uparrow$ & $=$ & & & (66) \\
\hline $\begin{array}{l}29 \\
\text { Overweight/ } \\
\text { obese men }\end{array}$ & & 13:27:60 & $37: 45: 18$ & & 12 wk & Baseline & Yes & & $\downarrow$ & & & $\downarrow$ & $=$ & $\downarrow$ & & (67) \\
\hline $\begin{array}{l}12 \text { With } \\
\text { metabolic } \\
\text { syndrome }\end{array}$ & $<50 \mathrm{~g} / \mathrm{d}$ & 16:22:62 & $45: 40: 15$ & & 4 wk & Baseline & Yes & 0.53 & $\downarrow$ & $\downarrow$ & $\downarrow$ & $\downarrow$ & $\downarrow$ & $\downarrow$ & ICAM1 $(\downarrow)$ & (68) \\
\hline 14 Obese & $<50 \mathrm{~g} / \mathrm{d}$ & 19:70:11 & $42: 23: 35$ & $\begin{array}{l}250-500 \mathrm{mg} \\
\text { DHA }\end{array}$ & $6 \mathrm{mo}$ & Baseline & Yes & & $\downarrow$ & $\downarrow$ & $\downarrow$ & $\downarrow$ & $=$ & $\downarrow$ & & (69) \\
\hline 28 Obese & $<50 \mathrm{~g} / \mathrm{d}$ & $20: 60: 20$ & & & $12 \mathrm{mo}$ & Baseline & Yes & & $=$ & $=$ & $\downarrow$ & $\downarrow$ & & & & (70) \\
\hline $\begin{array}{l}11 \text { Obese with } \\
\text { T2D }\end{array}$ & & 20:35:45 & & & $24 w k$ & Control & & & $\downarrow$ & $\downarrow$ & $\downarrow$ & & $\downarrow$ & $\downarrow$ & & (71) \\
\hline 10 Obese & & 20:25:55 & & & $8 w k$ & Baseline & & & $\downarrow$ & & & $=$ & & & & (21) \\
\hline 15 Firefighters & & $23: 29: 48$ & & & 4 wk & Baseline & Yes & & $\downarrow$ & $=$ & $=$ & $=$ & & & & (72) \\
\hline $\begin{array}{l}30 \text { Type } 2 \\
\text { diabetics }\end{array}$ & & $25: 26: 49$ & $43: 40: 17$ & & $6 \mathrm{mo}$ & Baseline & Yes & & $\downarrow$ & & & $=$ & $=$ & & $\operatorname{IL} 1 \mathrm{Ra}(\downarrow)$ & (73) \\
\hline $\begin{array}{l}43 \text { Severely } \\
\text { obese }\end{array}$ & $<30 \mathrm{~g} / \mathrm{d}$ & $32: 25: 43$ & & & $6 \mathrm{mo}$ & Baseline & Yes & & $\downarrow$ & & $\downarrow$ & $=$ & & & & (74) \\
\hline 75 Obese & $<40 \mathrm{~g} / \mathrm{d}$ & $34: 24: 41$ & $37: 41: 23$ & & $12 \mathrm{mo}$ & Low fat & Yes & & $\downarrow$ & & & & $=$ & $=$ & $\begin{array}{l}\text { IL8 }(=) \\
\text { ICAM1 }(\downarrow)\end{array}$ & (75) \\
\hline 262 Diabetics & & & & & $12 \mathrm{mo}$ & Baseline & & 0.31 & $\downarrow$ & & & $\downarrow$ & & & WBC $(\downarrow)$ & (22) \\
\hline $\begin{array}{l}11 \text { Multiple } \\
\text { sclerosis } \\
\text { subjects }\end{array}$ & $\begin{array}{l}<50 \mathrm{~g} / \mathrm{d} \\
\mathrm{CHO},>160 \mathrm{~g} \\
\text { fat }\end{array}$ & & & & $6 \mathrm{mo}$ & Control & & 1.4 & $\downarrow$ & $=$ & $=$ & & & & $\begin{array}{l}\text { ALOX5 mRNA } \\
(\downarrow)\end{array}$ & (76) \\
\hline $\begin{array}{l}22 \text { Healthy, } \\
\text { obese women }\end{array}$ & $<20-60 \mathrm{~g} / \mathrm{d}$ & & & & $3 \mathrm{mo}$ & Baseline & Yes & & $\downarrow$ & & & $\downarrow$ & & & & (77) \\
\hline $\begin{array}{l}6 \text { Overweight } \\
\text { divers }\end{array}$ & $<40 \mathrm{~g} / \mathrm{d}$ & & & & $7 d$ & Baseline & Yes & 0.9 & $\downarrow$ & & & & & $\downarrow$ & $\begin{array}{l}\text { Hyperoxic- } \\
\text { induced IL6 } \\
(\downarrow), I L 1 \beta(\downarrow)\end{array}$ & (78) \\
\hline
\end{tabular}

The up arrow indicates "increased" and the down arrow indicates "decreased," while = indicates "no change". 
that, in turn, may promote colon cancer formation $(84,85)$. It is also possible that immune cells within our intestinal lining become activated by saturated fats through direct activation of Toll-like receptors (ie. TLR 2 and 4) (86), leading to intestinal inflammation. Further studies evaluating the long-term effects of a low $\mathrm{CHO}$ diet that incorporates different types of fatty acids are therefore warranted.

\section{KETONE BODIES AND CANCER}

One of the main consequences of consuming a ketogenic diet is an increase in circulating ketone bodies, $\beta$-hydroxybutyrate $(\beta$ $\mathrm{HB}$ ), acetoacetate and acetone. As mentioned earlier, employing a ketogenic diet to prevent or treat cancer is particularly appealing because of the possibility that many cancer cells are unable to use ketone bodies as an energy source. However, since ketogenic diets are hard to adhere to, the use of ketone supplements is currently being evaluated as a way to reach ketosis in the absence of a ketogenic diet. This is being pursued on the assumption that ketone bodies themselves, rather than the lower levels of blood glucose and insulin associated with low $\mathrm{CHO}$, ketogenic diets, play a critical role in the reduction in tumors seen with ketogenic diets $(28,87)$. Of the three ketone bodies, $\beta-\mathrm{HB}$, has been reported to be uniquely anti-inflammatory (88), in part because it suppresses IL-1 $\beta$ expression in bone marrow derived macrophages (89), and promotes uncoupling protein 2 expression in mitochondria (90). The latter observation might account for its reported ability to lower oxidative stress (91). In addition, $\beta$-HB has been shown to inhibit HDAC activity and this may contribute to its protective effects against oxidative stress $(91,92)$ and thus extend lifespan (93).

\section{THE CASE FOR SOLUBLE FIBER AND RESISTANT STARCH}

While $\beta$ HB has been reported to have anti-inflammatory effects, we found that $\beta \mathrm{HB}$ at a level comparable to that typically found in nutritional ketosis is very weak in terms of reducing inflammation in human whole blood assays. In these ex-vivo studies, we challenged whole blood with $E$. coli bacteria. While $E$. coli stimulated a robust secretion of IL- 6 , IL-8, TNF- $\alpha$ and IL- $1 \beta$,
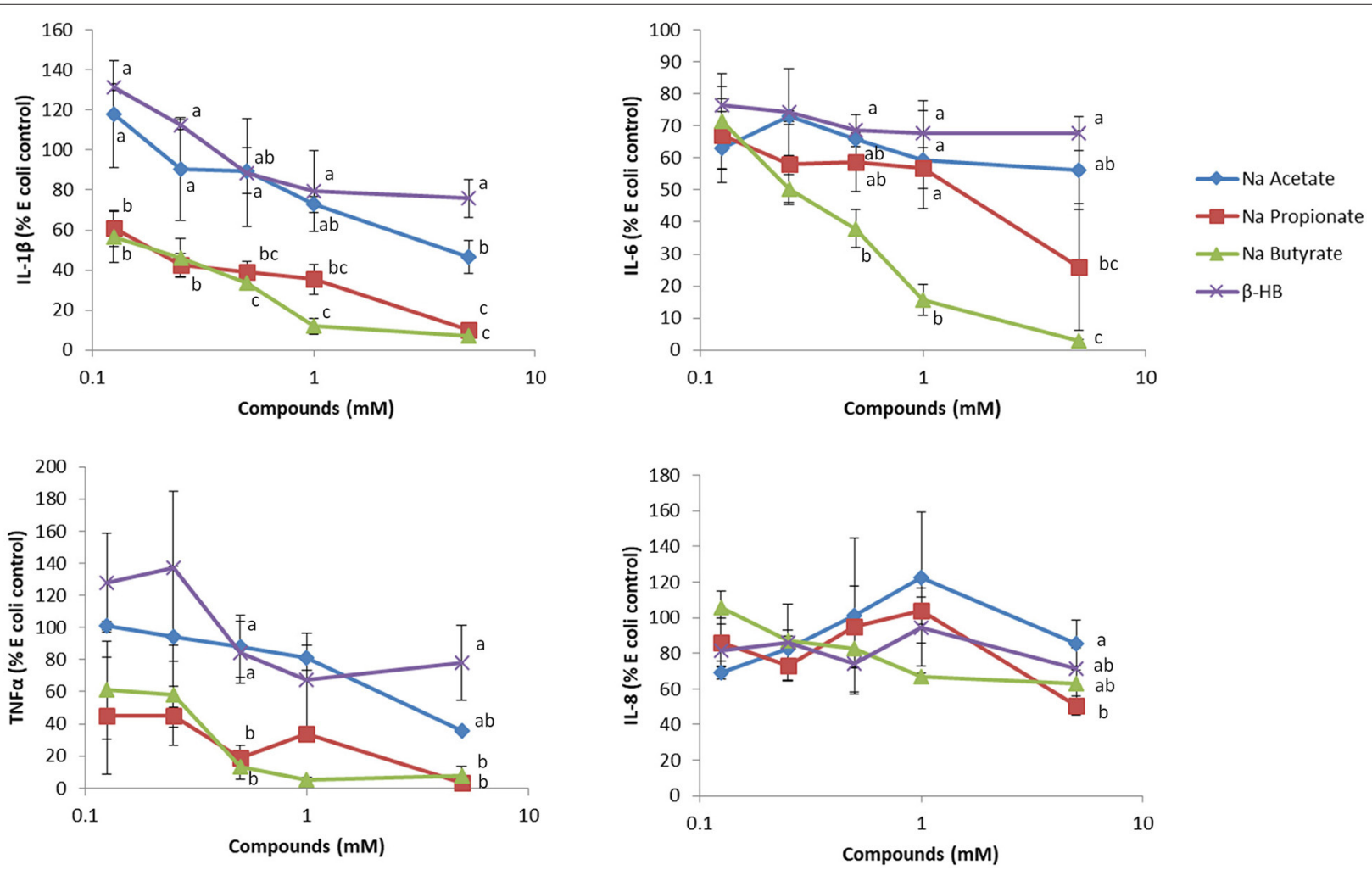

FIGURE 1 | The effect of sodium acetate, propionate, butyrate and $\beta$-hydroxybutyrate $(\beta$-HB) on $E$. coli-stimulated inflammatory cytokines from whole blood. Briefly, varying concentrations of SCFAs or $\beta$-HB dissolved in PBS were added to $50 \mu \mathrm{L}$ whole blood, collected in sodium heparin glass tubes, for $15 \mathrm{~min}$ at $37^{\circ} \mathrm{C}$, in a low (5\%) oxygen incubator, and then challenged with Escherichia coli (One Shot INV 110, Life Technologies, Burlington, ON) at a final concentration of $2 \times 104$ cells/mL for $7 \mathrm{~h}$ as previously described (94). PBS (100 $\mu \mathrm{L}$ ) was added to the whole blood, mixed well and upon centrifugation at $424 \times \mathrm{g}$ at $4{ }^{\circ} \mathrm{C}$ for $5 \mathrm{~min}$ in an Allegra $\mathrm{X}-12 \mathrm{R}$ centrifuge, the plasma was recovered for ELISA analysis $(n=3)$. This experiment was repeated two additional times, and results shown are representative of three independent experiments. Results are expressed as percentages, relative to E.coli-stimulated cells. The effect of the sodium acetate, butyrate, propionate and $\beta$-HB at each concentration on the cytokine/chemokine level was evaluated using one way ANOVA, followed by Tukey's multiple comparison post-hoc analysis. The different letters denote significant $(P<0.05)$ differences between treatments at the same concentration. Experiments using blood collected from human subjects were reviewed and approved by the joint Clinical Research Ethics Board of the University of British Columbia and the BC Cancer (\#H12-00727). 
$\beta$-HB had minimal effects in reducing this secretion (Figure 1). Since $\beta$-HB levels in blood during nutritional ketosis range from 0.5 to $3 \mathrm{mM}$ (95), we believe that our assay results are physiologically relevant.

On the other hand, when we tested the short chain fatty acids (SCFAs), i.e., acetate, propionate and butyrate, typically generated during fermentation of soluble fiber and resistant starch in the large intestine, we found far more pronounced antiinflammatory effects on blood samples. We tested these short chain fatty acids at concentrations typically found in peripheral and portal blood [ 0.1-0.4 mM (96)]. In the colon where SCFAs are produced by the gut microbiome, SCFAs can reach $150 \mathrm{mM}$ (97). Of the SCFAs tested, butyrate, the main source of energy for colonocytes (98), was the most anti-inflammatory, which is interesting since it has been reported to trigger apoptosis in colon cancer cells, therefore eliciting protection against colon cancer formation. The chemopreventive effect of butyrate is often attributed to its ability to inhibit HDAC activity, which in turn regulates gene expression and anti-inflammatory activity (99). Since low $\mathrm{CHO}$ diets are often low in both soluble fiber and resistant $\mathrm{CHOs,}$ which, as mentioned above, are precursors to gut-microbiome generated SCFAs, we suggest that their consumption, either by eating fruits and vegetables or by supplementation of low $\mathrm{CHO}$ diets, should be encouraged.

\section{CARBOHYDRATE RESTRICTION IN HUMAN STUDIES}

Because low $\mathrm{CHO}$ and ketogenic diets have been considered controversial, there have been very few human studies investigating the efficacy of $\mathrm{CHO}$ restriction for the treatment or prevention of cancer. There have been a few pilot or case studies with a small number of subjects, but a larger randomized controlled trial still needs to be performed. In one of these pilot studies, adherence was very poor, highlighting another potential roadblock to studies aiming to evaluate the efficacy of CHO-restricted diets in cancer treatment (100). There are, however, a growing number of reports in the literature on the effect of low $\mathrm{CHO}$ diets on metabolic profiles (Table 1). In these studies, low $\mathrm{CHO}$ diets, while not always effective in lowering blood glucose, were often reported to lower circulating insulin levels and other inflammatory markers such as CRP. When ketogenic diets were tested, increased levels of ketone bodies, such as $\beta-\mathrm{HB}$, were found. These are favorable changes that may work independently or together to reduce cancer risk (Table 1). With the increasing evidence of benefit in pre-clinical studies, we hope that more high quality studies will address the potential usefulness of low $\mathrm{CHO}$ diets in cancer.

\section{DISCUSSION}

While pre-clinical studies evaluating the safety and efficacy of low $\mathrm{CHO}$ diets in cancer prevention or treatment show promise, more studies are required to ensure the safety and efficacy of these diets in humans. Specifically, there is a need to evaluate the effect of different fatty acids in low $\mathrm{CHO}$ and ketogenic diets on inflammatory status, since this may help formulate a more optimal diet plan that not only facilitates weight loss, but also acts to reduce inflammation. In addition, the long-term safety of low $\mathrm{CHO}$ diets is an important question that has not been sufficiently addressed. While many clinical trials demonstrate that increased saturated fat intake in the context of low $\mathrm{CHO}$ diets does not lead to increased inflammation, these studies have been short-term. Low $\mathrm{CHO}$ diets high in saturated fats tend to include a substantial proportion of meat, and the long-term consumption of meat may pose health consequences that may not be detected in short-term studies. The effect of high meat consumption in low $\mathrm{CHO}$ diets, in particular, may increase cancer risk, especially colon cancer. It is also possible that an increase in meat consumption may lead to an increase in heterocyclic aromatic amines and polyaromatic hydrocarbons, which are carcinogens typically found in cooked meat or fish $(101,102)$. In addition, soluble fiber and resistant starch intake might be severely compromised, which would result in low $\mathrm{CHO}$ followers losing out on the health benefits potentially derived from them. It will thus be of interest to determine if low $\mathrm{CHO}$, high fat diets are associated with increased GI cancers if adopted long-term. In conclusion, it is evident from this perspective that further studies investigating the potential efficacy of low $\mathrm{CHO}$ diets in the prevention and treatment of cancer are both needed and warranted.

\section{DATA AVAILABILITY STATEMENT}

The original contributions generated in the study are included in the article/supplementary material, further inquiries can be directed to the corresponding author.

\section{ETHICS STATEMENT}

The studies involving human participants were reviewed and approved by the Clinical Research Ethics Board of the University of British Columbia and BC Cancer (\#H12-00727). The patients/participants provided their written informed consent to participate in this study.

\section{AUTHOR CONTRIBUTIONS}

IE wrote the first draft. GK edited, revised, and approved the manuscript. Both authors contributed to the article and approved the submitted version.

\section{FUNDING}

The research was supported by the Lotte and John Hecht Memorial Foundation (\#3968), with core support from the BC Cancer Foundation and BC Cancer.

\section{ACKNOWLEDGMENTS}

The authors would like to acknowledge Michelle Yeung for her assistance in the preparation of this manuscript. 


\section{REFERENCES}

1. Ma Y, Pagoto SL, Griffith JA, Merriam PA, Ockene IS, Hafner AR, et al. A dietary quality comparison of popular weight-loss plans. J Am Diet Assoc. (2007) 107:1786-91. doi: 10.1016/j.jada.2007.07.013

2. Feinman RD, Pogozelski WK, Astrup A, Bernstein RK, Fine EJ, Westman EC, et al. Dietary carbohydrate restriction as the first approach in diabetes management: critical review and evidence base. Nutrition. (2015) 31:1-13. doi: 10.1016/j.nut.2014.06.011

3. Neal EG, Chaffe H, Schwartz RH, Lawson MS, Edwards N, Fitzsimmons $\mathrm{G}$, et al. The ketogenic diet for the treatment of childhood epilepsy: a randomised controlled trial. Lancet Neurol. (2008) 7:500-6. doi: 10.1016/S1474-4422(08)70092-9

4. Atkins RC. Dr. Atkins' Diet Revolution: The High Calorie Way to Stay Thin Forever. New York, NY: McKay Co. (1972).

5. Ludwig DS. The Ketogenic diet: evidence for optimism but high-quality research needed. J Nutr. (2020) 150:1354-9. doi: 10.1093/jn/nxz308

6. Vander Heiden MG, Cantley LC, Thompson CB. Understanding the Warburg effect: the metabolic requirements of cell proliferation. Science. (2009) 324:1029-33. doi: 10.1126/science.1160809

7. Otto AM. Warburg effect(s)-a biographical sketch of Otto Warburg and his impacts on tumor metabolism. Cancer Metab. (2016) 4:5. doi: 10.1186/s40170-016-0145-9

8. Tisdale MJ, Brennan RA. Loss of acetoacetate coenzyme A transferase activity in tumours of peripheral tissues. Br J Cancer. (1983) 47:293-7. doi: 10.1038/bjc.1983.38

9. Skinner R, Trujillo A, Ma X, Beierle EA. Ketone bodies inhibit the viability of human neuroblastoma cells. J Pediatr Surg. (2009) 44:212-6; discussion 216. doi: 10.1016/j.jpedsurg.2008.10.042

10. Zhang J, Jia PP, Liu QL, Cong MH, Gao Y, Shi HP, e al. Low ketolytic enzyme levels in tumors predict ketogenic diet responses in cancer cell lines in vitro and in vivo. J Lipid Res. (2018) 59:625-34. doi: 10.1194/jlr.M082040

11. Mcgarry JD, Foster DW. Regulation of hepatic fatty acid oxidation and ketone body production. Annu Rev Biochem. (1980) 49:395-420. doi: 10.1146/annurev.bi.49.070180.002143

12. Puchalska P, Crawford PA. Multi-dimensional roles of ketone bodies in fuel metabolism, signaling, and therapeutics. Cell Metab. (2017) 25:262-84. doi: 10.1016/j.cmet.2016.12.022

13. Maurer GD, Brucker DP, Bahr O, Harter PN, Hattingen E, Walenta S, et al. Differential utilization of ketone bodies by neurons and glioma cell lines: a rationale for ketogenic diet as experimental glioma therapy. BMC Cancer. (2011) 11:315. doi: 10.1186/1471-2407-11-315

14. Volek JS, Sharman MJ, Gomez AL, Scheett TP, Kraemer WJ. An isoenergetic very low carbohydrate diet improves serum HDL cholesterol and triacylglycerol concentrations, the total cholesterol to HDL cholesterol ratio and postprandial pipemic responses compared with a low fat diet in normal weight, normolipidemic women. J Nutr. (2003) 133:2756-61. doi: $10.1093 /$ jn/133.9.2756

15. Fernandez ML, West KL. Mechanisms by which dietary fatty acids modulate plasma lipids. J Nutr. (2005) 135:2075-8. doi: 10.1093/jn/135.9.2075

16. Ference BA, Ginsberg HN, Graham I, Ray KK, Packard CJ, Bruckert E, et al. Low-density lipoproteins cause atherosclerotic cardiovascular disease. 1. Evidence from genetic, epidemiologic, and clinical studies. A consensus statement from the European Atherosclerosis Society Consensus Panel. Eur Heart J. (2017) 38:2459-72. doi: 10.1093/eurheartj/ehx144

17. Diamond DM, O'neill BJ, Volek JS. Low carbohydrate diet: are concerns with saturated fat, lipids, and cardiovascular disease risk justified? Curr Opin Endocrinol Diabetes Obes. (2020) 27:291-300. doi: 10.1097/MED.0000000000000568

18. Brinkworth GD, Noakes M, Buckley JD, Keogh JB, Clifton PM. Longterm effects of a very-low-carbohydrate weight loss diet compared with an isocaloric low-fat diet after 12 mo. Am J Clin Nutr. (2009) 90:23-32. doi: 10.3945/ajen.2008.27326

19. Bazzano LA, Hu T, Reynolds K, Yao L, Bunol C, Liu Y, et al. Effects of lowcarbohydrate and low-fat diets: a randomized trial. Ann Intern Med. (2014) 161:309-18. doi: 10.7326/M14-0180

20. De Souza RJ, Mente A, Maroleanu A, Cozma AI, Ha V, Kishibe T, et al. Intake of saturated and trans unsaturated fatty acids and risk of all cause mortality, cardiovascular disease, and type 2 diabetes: systematic review and meta-analysis of observational studies. BMJ (Clin Res Ed.). (2015) 351:h3978. doi: 10.1136/bmj.h3978

21. Stoernell CK, Tangney CC, Rockway SW. Short-term changes in lipoprotein subclasses and C-reactive protein levels of hypertriglyceridemic adults on low-carbohydrate and low-fat diets. Nutr Res. (2008) 28:443-9. doi: 10.1016/j.nutres.2008.03.013

22. Bhanpuri NH, Hallberg SJ, Williams PT, Mckenzie AL, Ballard KD, Campbell WW, et al. Cardiovascular disease risk factor responses to a type 2 diabetes care model including nutritional ketosis induced by sustained carbohydrate restriction at 1 year: an open label, non-randomized, controlled study. Cardiovasc Diabetol. (2018) 17:56. doi: 10.1186/s12933-018-0698-8

23. Gardner CD, Fortmann SP, Krauss RM. Association of small low-density lipoprotein particles with the incidence of coronary artery disease in men and women. JAMA. (1996) 276:875-81. doi: 10.1001/jama.1996.03540110029028

24. Weber DD, Aminazdeh-Gohari S, Kofler B. Ketogenic diet in cancer therapy. Aging (Albany NY). (2018) 10:164-5. doi: 10.18632/aging.101382

25. Tisdale MJ, Brennan RA, Fearon KC. Reduction of weight loss and tumour size in a cachexia model by a high fat diet. Br J Cancer. (1987) 56:39-43. doi: 10.1038/bjc.1987.149

26. Ho VW, Leung K, Hsu A, Luk B, Lai J, Shen SY, et al. A low carbohydrate, high protein diet slows tumor growth and prevents cancer initiation. Cancer Res. (2011) 71:4484-93. doi: 10.1158/0008-5472.CAN-10-3973

27. Hao GW, Chen YS, He DM, Wang HY, Wu GH, Zhang B. Growth of human colon cancer cells in nude mice is delayed by ketogenic diet with or without omega-3 fatty acids and medium-chain triglycerides. Asian Pac J Cancer Prev. (2015) 16:2061-8. doi: 10.7314/APJCP.2015.16.5.2061

28. Nakamura K, Tonouchi H, Sasayama A, Ashida K. A ketogenic formula prevents tumor progression and cancer cachexia by attenuating systemic inflammation in colon 26 tumor-bearing mice. Nutrients. (2018) 10:206. doi: $10.3390 /$ nu10020206

29. Otto C, Kaemmerer U, Illert B, Muehling B, Pfetzer N, Wittig R, et al. Growth of human gastric cancer cells in nude mice is delayed by a ketogenic diet supplemented with omega-3 fatty acids and medium-chain triglycerides. BMC Cancer. (2008) 8:122. doi: 10.1186/1471-2407-8-122

30. Freedland SJ, Mavropoulos J, Wang A, Darshan M, Demark-Wahnefried W, Aronson WJ, et al. Carbohydrate restriction, prostate cancer growth, and the insulin-like growth factor axis. Prostate. (2008) 68:11-9. doi: $10.1002 /$ pros. 20683

31. Mavropoulos JC, Buschemeyer WC, III, Tewari AK, Rokhfeld D, Pollak M, Zhao Y, et al. The effects of varying dietary carbohydrate and fat content on survival in a murine LNCaP prostate cancer xenograft model. Cancer Prev Res (Phila). (2009) 2:557-65. doi: 10.1158/1940-6207.CAPR-08-0188

32. Shukla SK, Gebregiworgis T, Purohit V, Chaika NV, Gunda V, Radhakrishnan $\mathrm{P}$, et al. Metabolic reprogramming induced by ketone bodies diminishes pancreatic cancer cachexia. Cancer Metab. (2014) 2:18. doi: 10.1186/2049-3002-2-18

33. Martuscello RT, Vedam-Mai V, Mccarthy DJ, Schmoll ME, Jundi MA, Louviere CD, et al. A supplemented high-fat low-carbohydrate diet for the treatment of glioblastoma. Clin Cancer Res. (2016) 22:2482-95. doi: 10.1158/1078-0432.CCR-15-0916

34. Mukherjee P, Augur ZM, Li M, Hill C, Greenwood B, Domin MA, et al. Therapeutic benefit of combining calorie-restricted ketogenic diet and glutamine targeting in late-stage experimental glioblastoma. Commun Biol. (2019) 2:200. doi: 10.1038/s42003-019-0455-x

35. Aggarwal A, Yuan Z, Barletta JA, Lorch JH, Nehs MA. Ketogenic diet combined with antioxidant $\mathrm{N}$-acetylcysteine inhibits tumor growth in a mouse model of anaplastic thyroid cancer. Surgery. (2020) 167:87-93. doi: 10.1016/j.surg.2019.06.042

36. Xia S, Lin R, Jin L, Zhao L, Kang HB, Pan Y, et al. Prevention of dietary-fatfueled ketogenesis attenuates BRAF V600E tumor growth. Cell Metab. (2017) 25:358-73. doi: 10.1016/j.cmet.2016.12.010

37. Ho VW, Hamilton MJ, Dang NH, Hsu BE, Adomat HH, Guns ES, et al. A low carbohydrate, high protein diet combined with celecoxib markedly reduces metastasis. Carcinogenesis. (2014) 35:2291-9. doi: 10.1093/carcin/bgu147

38. Fokidis HB, Yieng Chin M, Ho VW, Adomat HH, Soma KK, Fazli L, et al. A low carbohydrate, high protein diet suppresses intratumoral androgen synthesis and slows castration-resistant prostate tumor 
growth in mice. J Steroid Biochem Mol Biol. (2015) 150:35-45. doi: 10.1016/j.jsbmb.2015.03.006

39. Zitvogel L, Pietrocola F, Kroemer G. Nutrition, inflammation and cancer. Nat Immunol. (2017) 18:843-50. doi: 10.1038/ni.3754

40. Grivennikov SI, Greten FR, Karin M. Immunity, inflammation, and cancer. Cell. (2010) 140:883-99. doi: 10.1016/j.cell.2010.01.025

41. Elisia I, Cho B, Hay M, Li MY, Hofs E, Lam V, et al. The effect of diet and exercise on tobacco carcinogen-induced lung cancer. Carcinogenesis. (2019) 40:448-60. doi: 10.1093/carcin/bgz060

42. Wallace TC. Health effects of coconut oil-a narrative review of current evidence. J Am Coll Nutr. (2019) 38:97-107. doi: 10.1080/07315724.2018.1497562

43. Papamandjaris AA, Macdougall DE, Jones PJH. Medium chain fatty acid metabolism and energy expenditure: obesity treatment implications. Life Sci. (1998) 62:1203-15. doi: 10.1016/S0024-3205(97)01143-0

44. Elisia I, Hay M, Cho B, Yeung M, Kowalski S, Wong J, et al. Low carbohydrate diets containing soy protein and fish oil slow the growth of established NNK-induced lung tumors. Carcinogenesis. (2020) 41:1083-93. doi: 10.1093/carcin/bgaa028

45. Coussens LM, Werb Z. Inflammation and cancer. Nature. (2002) 420:860-7. doi: $10.1038 /$ nature 01322

46. Hanahan D, Weinberg Robert A. Hallmarks of cancer: the next generation. Cell. (2011) 144:646-74. doi: 10.1016/j.cell.2011.02.013

47. Carotenuto F, Albertini MC, Coletti D, Vilmercati A, Campanella L, Darzynkiewicz Z, et al. How diet intervention via modulation of DNA damage response through microRNAs may have an effect on cancer prevention and aging, an in silico study. Int J Mol Sci. (2016) 17:752. doi: 10.3390/ijms17050752

48. Shi H, Kokoeva MV, Inouye K, Tzameli I, Yin H, Flier JS. TLR4 links innate immunity and fatty acid-induced insulin resistance. J Clin Invest. (2006) 116:3015-25. doi: 10.1172/JCI28898

49. Cani PD, Amar J, Iglesias MA, Poggi M, Knauf C, Bastelica D, et al. Metabolic endotoxemia initiates obesity and insulin resistance. Diabetes. (2007) 56:1761-72. doi: 10.2337/db06-1491

50. Fritsche KL. The science of fatty acids and inflammation. Adv Nutr (Bethesda, Md.). (2015) 6:293S-301S. doi: 10.3945/an.114.006940

51. Calder PC. Omega-3 polyunsaturated fatty acids and inflammatory processes: nutrition or pharmacology? Br J Clin Pharmacol. (2013) 75:64562. doi: 10.1111/j.1365-2125.2012.04374.x

52. Keogh JB, Brinkworth GD, Noakes M, Belobrajdic DP, Buckley JD, Clifton PM. Effects of weight loss from a very-low-carbohydrate diet on endothelial function and markers of cardiovascular disease risk in subjects with abdominal obesity. Am J Clin Nutr. (2008) 87:567-76. doi: 10.1093/ajcn/87.3.567

53. Piracha ZZ, Saeed U, Kim J, Kwon H, Chwae YJ, Lee HW, et al. An alternatively spliced sirtuin 2 isoform 5 inhibits hepatitis B virus replication from cccDNA by repressing epigenetic modifications made by histone lysine methyltransferases. J Virol. (2020) 94:e00926-20. doi: 10.1128/JVI. 00926-20

54. Davis NJ, Crandall JP, Gajavelli S, Berman JW, Tomuta N, Wylie-Rosett J, et al. Differential effects of low-carbohydrate and low-fat diets on inflammation and endothelial function in diabetes. J Diabetes Complications. (2011) 25:371-6. doi: 10.1016/j.jdiacomp.2011.08.001

55. Mohorko N, Cernelic-Bizjak M, Poklar-Vatovec T, Grom G, Kenig S, Petelin A, et al. Weight loss, improved physical performance, cognitive function, eating behavior, and metabolic profile in a 12-week ketogenic diet in obese adults. Nutr Res. (2019) 62:64-77. doi: 10.1016/j.nutres.2018.11.007

56. Rosenbaum M, Hall KD, Guo J, Ravussin E, Mayer LS, Reitman ML, et al. Glucose and lipid homeostasis and inflammation in humans following an isocaloric ketogenic diet. Obesity (Silver Spring). (2019) 27:971-81. doi: 10.1002/oby.22468

57. Peairs AT, Rankin JW. Inflammatory response to a high-fat, lowcarbohydrate weight loss diet: effect of antioxidants. Obesity (Silver Spring). (2008) 16:1573-8. doi: 10.1038/oby.2008.252

58. Cipryan L, Plews DJ, Ferretti A, Maffetone PB, Laursen PB, Effects of a 4-week very low-carbohydrate diet on high-intensity interval training responses. J Sports Sci Med. (2018) 17:259-68. doi: $10.1177 / 0260106020903206$
59. Sharman MJ, Volek JS. Weight loss leads to reductions in inflammatory biomarkers after a very-low-carbohydrate diet and a low-fat diet in overweight men. Clin Sci (Lond). (2004) 107:365-9. doi: 10.1042/CS20040111

60. Ruth MR, Port AM, Shah M, Bourland AC, Istfan NW, Nelson KP, et al. Consuming a hypocaloric high fat low carbohydrate diet for 12 weeks lowers C-reactive protein, and raises serum adiponectin and high density lipoprotein-cholesterol in obese subjects. Metabolism. (2013) 62:1779-87. doi: 10.1016/j.metabol.2013.07.006

61. Myette-Cote E, Durrer C, Neudorf H, Bammert TD, Botezelli JD, Johnson JD, et al. The effect of a short-term low-carbohydrate, high-fat diet with or without postmeal walks on glycemic control and inflammation in type 2 diabetes: a randomized trial. Am J Physiol Regul Integr Comp Physiol. (2018) 315:R1210-9. doi: 10.1152/ajpregu.00240.2018

62. Ballard KD, Quann EE, Kupchak BR, Volk BM, Kawiecki DM, Fernandez ML, et al. Dietary carbohydrate restriction improves insulin sensitivity, blood pressure, microvascular function, and cellular adhesion markers in individuals taking statins. Nutr Res. (2013) 33:905-12. doi: 10.1016/j.nutres.2013.07.022

63. Paoli A, Moro T, Bosco G, Bianco A, Grimaldi KA, Camporesi E, et al. Effects of n-3 polyunsaturated fatty acids (omega-3) supplementation on some cardiovascular risk factors with a ketogenic Mediterranean diet. Mar Drugs. (2015) 13:996-1009. doi: 10.3390/md13020996

64. Forsythe CE, Phinney SD, Fernandez ML, Quann EE, Wood RJ, Bibus DM, et al. Comparison of low fat and low carbohydrate diets on circulating fatty acid composition and markers of inflammation. Lipids. (2008) 43:65-77. doi: $10.1007 / \mathrm{s} 11745-007-3132-7$

65. Forsythe CE, Phinney SD, Feinman RD, Volk BM, Freidenreich D, Quann E, et al. Limited effect of dietary saturated fat on plasma saturated fat in the context of a low carbohydrate diet. Lipids. (2010) 45:947-62. doi: 10.1007/s11745-010-3467-3

66. Rankin JW, Turpyn AD. Low carbohydrate, high fat diet increases Creactive protein during weight loss. J Am Coll Nutr. (2007) 26:163-9. doi: 10.1080/07315724.2007.10719598

67. Wood RJ, Volek JS, Davis SR, Dell'ova C, Fernandez ML. Effects of a carbohydrate-restricted diet on emerging plasma markers for cardiovascular disease. Nutr Metab (Lond). (2006) 3:19. doi: 10.1186/1743-7075-3-19

68. Gyorkos A, Baker MH, Miutz LN, Lown DA, Jones MA, HoughtonRahrig LD. Carbohydrate-restricted diet and high-intensity interval training exercise improve cardio-metabolic and inflammatory profiles in metabolic syndrome: a randomized crossover trial. Cureus. (2019) 11:e5596. doi: 10.7759/cureus.5596

69. De Luis D, Domingo JC, Izaola O, Casanueva FF, Bellido D, Sajoux I. Effect of DHA supplementation in a very low-calorie ketogenic diet in the treatment of obesity: a randomized clinical trial. Endocrine. (2016) 54:11122. doi: $10.1007 / \mathrm{s} 12020-016-0964-\mathrm{z}$

70. Perticone M, Maio R, Sciacqua A, Suraci E, Pinto A, Pujia R, et al. Ketogenic diet-induced weight loss is associated with an increase in vitamin D levels in obese adults. Molecules. (2019) 24:2499. doi: 10.3390/molecules24132499

71. Asle Mohammadi Zadeh M, Kargarfard M, Marandi SM, Habibi A. Diets along with interval training regimes improves inflammatory \& antiinflammatory condition in obesity with type 2 diabetes subjects. J Diabetes Metab Disord. (2018) 17:253-67. doi: 10.1007/s40200-018-0368-0

72. Waldman HS, Smith JW, Lamberth J, Fountain BJ, Bloomer RJ, Butawan $\mathrm{MB}$, et al. A 28-day carbohydrate-restricted diet improves markers of cardiovascular disease in professional firefighters. J Strength Cond Res. (2020) 34:2785-92. doi: 10.1519/JSC.0000000000003749

73. Jonasson L, Guldbrand H, Lundberg AK, Nystrom FH. Advice to follow a low-carbohydrate diet has a favourable impact on low-grade inflammation in type 2 diabetes compared with advice to follow a low-fat diet. Ann Med. (2014) 46:182-7. doi: 10.3109/07853890.2014.894286

74. Seshadri P, Iqbal N, Stern L, Williams M, Chicano KL, Daily DA, et al. A randomized study comparing the effects of a low-carbohydrate diet and a conventional diet on lipoprotein subfractions and C-reactive protein levels in patients with severe obesity. Am J Med. (2004) 117:398-405. doi: 10.1016/j.amjmed.2004.04.009

75. Hu T, Yao L, Reynolds K, Whelton PK, Niu T, Li S, et al. The effects of a low-carbohydrate diet vs. a low-fat diet on novel cardiovascular 
risk factors: a randomized controlled trial. Nutrients. (2015) 7:7978-94. doi: 10.3390/nu7095377

76. Bock M, Karber M, Kuhn H. Ketogenic diets attenuate cyclooxygenase and lipoxygenase gene expression in multiple sclerosis. EBioMedicine. (2018) 36:293-303. doi: 10.1016/j.ebiom.2018.08.057

77. O’brien KD, Brehm BJ, Seeley RJ, Bean J, Wener MH, Daniels S, et al. Diet-induced weight loss is associated with decreases in plasma serum amyloid a and C-reactive protein independent of dietary macronutrient composition in obese subjects. J Clin Endocrinol Metab. (2005) 90:2244-9. doi: 10.1210/jc.2004-1011

78. Bosco G, Rizzato A, Quartesan S, Camporesi E, Mangar D, Paganini M, et al. Effects of the Ketogenic diet in overweight divers breathing enriched air nitrox. Sci Rep. (2018) 8:2655. doi: 10.1038/s41598-018-20933-w

79. Calder PC. Fatty acids and inflammation: the cutting edge between food and pharma. Eur J Pharmacol. (2011) 668:S50-8. doi: 10.1016/j.ejphar.2011.05.085

80. Katan MB, Deslypere JP, Van Birgelen AP, Penders M, Zegwaard M. Kinetics of the incorporation of dietary fatty acids into serum cholesteryl esters, erythrocyte membranes, and adipose tissue: an 18-month controlled study. $J$ Lipid Res. (1997) 38:2012-22. doi: 10.1016/S0022-2275(20)37132-7

81. Elisia I, Lam V, Cho B, Hay M, Li MY, Kapeluto J, et al. Exploratory examination of inflammation state, immune response and blood cell composition in a human obese cohort to identify potential markers predicting cancer risk. PLoS ONE. (2020) 15:e0228633. doi: 10.1371/journal.pone.0228633

82. Mardinoglu A, Wu H, Bjornson E, Zhang C, Hakkarainen A, Rasanen SM, et al. An integrated understanding of the rapid metabolic benefits of a carbohydrate-restricted diet on hepatic steatosis in humans. Cell Metab. (2018) 27:559-71.e555. doi: 10.1016/j.cmet.2018.01.005

83. Smidowicz A, Regula J. Effect of nutritional status and dietary patterns on human serum C-reactive protein and interleukin- 6 concentrations. $A d v$ Nutr. (2015) 6:738-47. doi: 10.3945/an.115.009415

84. Bernstein C, Holubec H, Bhattacharyya AK, Nguyen H, Payne CM, Zaitlin B, et al. Carcinogenicity of deoxycholate, a secondary bile acid. Arch Toxicol. (2011) 85:863-71. doi: 10.1007/s00204-011-0648-7

85. Fu T, Coulter S, Yoshihara E, Oh TG, Fang S, Cayabyab F, et al. FXR regulates intestinal cancer stem cell proliferation. Cell. (2019) 176:1098-112.e1018. doi: 10.1016/j.cell.2019.01.036

86. Hwang DH, Kim JA, Lee JY. Mechanisms for the activation of Toll-like receptor $2 / 4$ by saturated fatty acids and inhibition by docosahexaenoic acid. Eur J Pharmacol. (2016) 785:24-35. doi: 10.1016/j.ejphar.2016.04.024

87. Fine EJ, Segal-Isaacson CJ, Feinman RD, Herszkopf S, Romano MC, Tomuta $\mathrm{N}$, et al. Targeting insulin inhibition as a metabolic therapy in advanced cancer: a pilot safety and feasibility dietary trial in 10 patients. Nutrition. (2012) 28:1028-35. doi: 10.1016/j.nut.2012.05.001

88. Fu SP, Wang JF, Xue WJ, Liu HM, Liu BR, Zeng YL, et al. Anti-inflammatory effects of BHBA in both in vivo and in vitro Parkinson's disease models are mediated by GPR109A-dependent mechanisms. J Neuroinflammation. (2015) 12:9. doi: 10.1186/s12974-014-0230-3

89. Goldberg EL, Asher JL, Molony RD, Shaw AC, Zeiss CJ, Wang C, et al. Beta-hydroxybutyrate deactivates neutrophil NLRP3 inflammasome to relieve gout flares. Cell Rep. (2017) 18:2077-87. doi: 10.1016/j.celrep.2017. 02.004
90. Sullivan PG, Rippy NA, Dorenbos K, Concepcion RC, Agarwal AK, Rho JM. The ketogenic diet increases mitochondrial uncoupling protein levels and activity. Ann Neurol. (2004) 55:576-80. doi: 10.1002/ana.20062

91. Shimazu T, Hirschey MD, Newman J, He W, Shirakawa K, Le Moan $\mathrm{N}$, et al. Suppression of oxidative stress by beta-hydroxybutyrate, an endogenous histone deacetylase inhibitor. Science. (2013) 339:211-4. doi: $10.1126 /$ science. 1227166

92. Maalouf M, Sullivan PG, Davis L, Kim DY, Rho JM. Ketones inhibit mitochondrial production of reactive oxygen species production following glutamate excitotoxicity by increasing NADH oxidation. Neuroscience. (2007) 145:256-64. doi: 10.1016/j.neuroscience.2006.11.065

93. Edwards C, Canfield J, Copes N, Rehan M, Lipps D, Bradshaw PC. D-betahydroxybutyrate extends lifespan in C. elegans. Aging (Albany NY). (2014) 6:621-44. doi: 10.18632/aging.100683

94. Elisia I, Pae HB, Lam V, Cederberg R, Hofs E, Krystal G. Comparison of RAW264.7, human whole blood and PBMC assays to screen for immunomodulators. J Immunol Methods. (2018) 452:26-31. doi: 10.1016/j.jim.2017.10.004

95. Volek J, Phinney SD. The Art and Science of Low Carbohydrate Performance: A Revolutionary Program to Extend your Physical and Mental Performance. Beyond Obesity LLC (2012).

96. Cummings JH, Pomare EW, Branch WJ, Naylor CP, Macfarlane GT. Short chain fatty acids in human large intestine, portal, hepatic and venous blood. Gut. (1987) 28:1221-7. doi: 10.1136/gut.28.10.1221

97. Mihaylova MM, Stratton MS. Chapter 23-Short chain fatty acids as epigenetic and metabolic regulators of neurocognitive health and disease. In: Ferguson BS, editor. Nutritional Epigenomics. Cambridge MA: Academic Press (2019). p. 381-97. doi: 10.1016/B978-0-12-816843-1.00023-0

98. Roediger WE. Utilization of nutrients by isolated epithelial cells of the rat colon. Gastroenterology. 83:424-9. doi: 10.1016/S0016-5085(82)80339-9

99. Hamer HM, Jonkers D, Venema K, Vanhoutvin S, Troost FJ, Brummer R-J. Review article: the role of butyrate on colonic function. Aliment Pharmacol Ther. (2008) 27:104-19. doi: 10.1111/j.1365-2036.2007.03562.x

100. Schmidt M, Pfetzer N, Schwab M, Strauss I, Kammerer U. Effects of a ketogenic diet on the quality of life in 16 patients with advanced cancer: a pilot trial. Nutr Metab (Lond). (2011) 8:54. doi: 10.1186/1743-7075-8-54

101. Sugimura T, Wakabayashi K, Nakagama H, Nagao M. Heterocyclic amines: mutagens/carcinogens produced during cooking of meat and fish. Cancer Sci. (2004) 95:290-9. doi: 10.1111/j.1349-7006.2004.tb03205.x

102. Turesky RJ. Formation and biochemistry of carcinogenic heterocyclic aromatic amines in cooked meats. Toxicol Lett. (2007) 168:219-27. doi: $10.1016 /$ j.toxlet.2006.10.018

Conflict of Interest: The authors declare that the research was conducted in the absence of any commercial or financial relationships that could be construed as a potential conflict of interest.

Copyright (๑) 2021 Elisia and Krystal. This is an open-access article distributed under the terms of the Creative Commons Attribution License (CC BY). The use, distribution or reproduction in other forums is permitted, provided the original author(s) and the copyright owner(s) are credited and that the original publication in this journal is cited, in accordance with accepted academic practice. No use, distribution or reproduction is permitted which does not comply with these terms. 